\author{
Katarzyna CHUDY-LASKOWSKA ${ }^{1}$ \\ Joanna WOŹNIAK ${ }^{2}$ \\ Beata WELCZ ${ }^{3}$
}

\title{
STAN BEZPIECZEŃSTWA NA POLSKICH DROGACH W 2013 ROKU
}

\begin{abstract}
Transport drogowy stanowi jeden z kluczowych obszarów funkcjonowania współczesnej Polski. Umożliwia mobilność ludności oraz zaspokaja popyt na szybkie dostawy towarów. Narastająca liczba pojazdów samochodowych oraz wzrost ruchu drogowego powodują, że konieczny staje się rozwój sieci drogowych oraz ich zmian jakościowych. Infrastruktura transportu drogowego powinna zatem spełniać wszystkie niezbędne warunki, które będą w stanie sprostać wciąż narastającym wymaganiom społeczeństwa. Rozbudowa sieci dróg czy modernizacja już istniejących to warunek konieczny zapewniający bezpieczne i szybkie przemieszczanie się. W publikacji zwrócono również uwagę na skutki, jakie ponoszą za sobą wypadki oraz kolizje na polskich drogach. Według Krajowej Rady Bezpieczeństwa Ruchu Drogowego w 2013 r. ich koszty wyniosły 41,9 mld złotych, co stanowiło $2,99 \%$ PKB. Srodki te mogłyby być z powodzeniem wykorzystywane do innych społecznych celów, jak na przykład edukacja, szkolnictwo wyższe, czy też służba zdrowia. W związku z tym głównym celem niniejszego artykułu jest przedstawienie stanu bezpieczeństwa na Polskich drogach z podziałem na województwa. W pracy zamieszczono wyniki badań dotyczących wypadków drogowych oraz ich ofiar w roku 2013. Do analizy danych wykorzystano program Statistica 10.PL. Dane zaczerpnięto ze strony Głównego Urzędu Statystycznego. Analizę wykonano, wykorzystując metodę Warda. Za jej pomocą wyodrębniono trzy skupienia, które pozwoliły zidentyfikować województwa podobne do siebie pod względem stanu bezpieczeństwa ruchu drogowego. Badania mogą zostać wykorzystane przez władze lokalne w celu wyodrębnienia obszarów, które należy zmodernizować, co tym samym przyczyni się do poprawy bezpieczeństwa w ruchu drogowym.

Słowa kluczowe: transport drogowy, bezpieczeństwo, ofiary wypadków, metoda Warda
\end{abstract}

\section{WPROWADZENIE}

Transport drogowy odgrywa ważną rolę w funkcjonowaniu gospodarki kraju. W łańcuchu logistycznym ma istotne znaczenie w przemieszczaniu surowców, materiałów oraz wyrobów gotowych ${ }^{4}$. Cechuje się nieograniczoną dostępnością, dużą szybkością i terminowością przewozu oraz możliwością dowozu „od producenta do konsumenta”. ${ }^{5}$. Na znaczący przyrost liczby pojazdów samochodowych wpływają również zmiana stylu życia oraz wzrost mobilności Polaków. Te czynniki rzutują z kolei na zwiększenie liczby wy-

\footnotetext{
${ }^{1}$ Dr Katarzyna Chudy-Laskowska, Katedra Metod Ilościowych, Politechnika Rzeszowska, al. Powstańców Warszawy 8, 35-959 Rzeszów, tel.: 1786519 06, e-mail: kacha877@ prz.rzeszow.pl (autor korespondencyjny).

${ }^{2}$ Mgr inż. Joanna Woźniak, Katedra Systemów Zarządzania i Logistyki, Politechnika Rzeszowska, al. Powstańców Warszawy 8, 35-959 Rzeszów, tel.: 1786510 73, e-mail: j.wozniak@prz.edu.pl

${ }^{3}$ Mgr inż. Beata Welcz, Lear Corporation, 37-500 Jarosław, ul. 3 Maja 85, e-mail: BWelcz@lear.com

${ }^{4}$ J. Baran i in., Logistyka. Wybrane zagadnienia, SGGW, Warszawa 2008, s. 80.

${ }^{5}$ M. Stajniak i in., Transport i spedycja, Instytut Logistyki i Magazynowania, Poznań 2008, s. 14-15.
} 
padków. Według badań Światowej Organizacji Zdrowia wypadki drogowe plasują się obecnie na 7. miejscu wśród największych zagrożeń życia i zdrowia ludzkiego. Za ćwierć wieku mogą znaleźć się na 2. miejscu zaraz po chorobach słuchu występujących na tle nerwowym, które wywołane będą hałasem spowodowanym przez środki transportu ${ }^{6}$.

Warto również zwrócić uwagę na to, że zapewnienie bezpieczeństwa w ruchu drogowym jest ważnym procesem społecznym, który $\mathrm{z}$ kolei jest ściśle powiązany $\mathrm{z}$ aspektami ekonomicznymi. Wypadki stanowią znaczący problem z powodu masowości zjawiska oraz jego tragicznych konsekwencji ${ }^{7}$. Ponadto na wypadki i kolizje drogowe co roku przeznaczane są środki, które teoretycznie mogłyby być wykorzystywane do innych społecznych celów. Krajowa Rada Bezpieczeństwa Ruchu Drogowego podaje ${ }^{8}$, że w 2013 r. łączna suma kosztów wszystkich zdarzeń drogowych w Polsce została oszacowana na poziomie 49,1 mld złotych, z czego 34,2 mld złotych stanowiły same wypadki drogowe, a 14,9 mld złotych zostały przeznaczone na koszty związane z kolizjami. Suma ta stanowi $2,99 \% \mathrm{PKB}_{2013}$.

W związku z tym głównym celem niniejszego artykułu jest przedstawienie stanu bezpieczeństwa na polskich drogach $\mathrm{z}$ podziałem na województwa. W publikacji zamieszczono również informacje dotyczące głównych przyczyn wypadków oraz ich skutków. Dane zostały zaczerpnięte ze strony Głównego Urzędu Statystycznego i obejmują rok 2013. Badania wykonano za pomocą metody Warda. Do analizy danych wykorzystano program STATISTICA 10. PL i Microsoft Excel.

\section{PRZYCZYNY WYPADKÓW DROGOWYCH W POLSCE}

W Polsce w ciągu ostatnich kilku lat można zaobserwować dynamiczną rozbudowę i modernizację infrastruktury drogowej. Zmiany dotyczą zarówno autostrad, jak i innych dróg krajowych i lokalnych. Jest to związane głównie z realizacją programów unijnych oraz organizacją Mistrzostw Europy w Piłce Nożnej EURO 2012.

Polska oraz pozostałe kraje Europy podjęły działania, których głównym celem jest zmniejszenie wypadkowości i poprawienie bezpieczeństwa ruchu drogowego ${ }^{9}$. Ponadto w celu utworzenia jednolitego europejskiego obszaru transportu Komisja Europejska opublikowała 28 marca 2011 r. nową Białą Księgę zatytułowaną Plan utworzenia jednolitego europejskiego obszaru transportu - dażenie do osiagnięcia konkurencyjnego i oszczędnego zasobowo systemu transportu. Dokument ten przedstawia sektor transportu, który będzie się charakteryzować wysokim poziomem konkurencyjności, a oprócz tego będzie minimalizował wykorzystywanie nieodnawialnych surowców naturalnych. Nowa polityka transportowa Unii Europejskiej ustanowiła cele strategiczne, takie jak ${ }^{10}$ :

1. Do roku 2030 zmniejszenie o 50\% liczby samochodów z napędem konwencjonalnym w ruchu miejskim, a do roku 2050 całkowite ich wyeliminowanie.

2. Uzyskanie do 2050 r. 40-procentowego udziału w zastosowaniu paliw niskoemisyjnych w lotnictwie .

\footnotetext{
${ }^{6} \mathrm{http}: / / \mathrm{www}$. who.int/en/.

${ }^{7}$ K. Chudy- Laskowska, T. Pisula, Prognoza liczby wypadków drogowych w Polsce, ,Logistyka” 2014/6

${ }^{8}$ Krajowa Rada Bezpieczeństwa Ruchu Drogowego, Wycena kosztów wypadków i kolizji drogowych na sieci dróg w Polsce na koniec roku 2013, Warszawa 2014.

${ }^{9}$ Globalny Plan Dekady Działań na rzecz Bezpieczeństwa Ruchu Drogowego 2011-2020, ITS BRD 2011/1, http://www.who.int/roadsafety/decade_of_action/plan/plan_english.pdf.

${ }^{10} \mathrm{http}: / /$ eur-lex.europa.eu/legal-content/pl/TXT/PDF/?uri=CELEX:52011DC0144.
} 
3. Do 2030 r. odciążenie transportu drogowego ładunków o 30\% na rzecz innych gałęzi transportu (transport morski, kolej) na dystansie powyżej $300 \mathrm{~km}$, a do 2050 r. 50\% ładunków. Może to być zrealizowane przez utworzenie ekologicznych i efektywnych korytarzy transportowych.

4. Ukończenie do 2050 r. szybkiej europejskiej sieci kolejowej, przy jednoczesnym zachowaniu gęstej sieci kolejowej w państwach członkowskich.

5. Utworzenie do $2030 \mathrm{r}$. w pełni funkcjonalnej ogólnounijnej sieci bazowej TEN-T i osiągnięcie wysokiej jakości oraz przepustowości tej sieci do $2050 \mathrm{r}$.

6. Powiązanie sieci bazowej TEN-T z siecią kolejową do $2050 \mathrm{r}$.

7. Wprowadzenie w Europie systemów zarządzania transportem (SESAR, ITS, LRIT, ERTMS, SSN, RIS) oraz Galileo do $2020 \mathrm{r}$.

8. Do 2020 r. w obszarze transportu multimodalnego ustanowienie ram europejskiego systemu zarządzania, informacji i płatności.

9. Zmniejszenie liczby ofiar śmiertelnych w transporcie drogowym do zera w $2050 \mathrm{r}$.

10. Całościowa internalizacja kosztów transportu zewnętrznego.

Cele te ujednolicą oraz zrównoważą europejski obszar transportu. Mobilność w dzisiejszych czasach jest niezwykle istotna zarówno dla rynku wewnętrznego, jak i dla wzrostu jakości życia wśród obywateli. Sektor transportu tworzy nowe miejsca pracy oraz umożliwia wzrost gospodarczy. Mimo to poziom bezpieczeństwa na polskich drogach jest niski. Fakt ten odzwierciedlają europejskie statystyki, w których Polska zajmuje jedno z ostatnich miejsc. Stan infrastruktury drogowej nie jest zwykle wskazywany jako bezpośrednia przyczyna wypadków. Należy jednak pamiętać, że niedostosowanie parametrów technicznych do natężenia ruchu może sprzyjać popełnianiu przez kierowców błędów, które z kolei stwarzają zagrożenie dla innych uczestników ruchu drogowego ${ }^{11}$.

Do najczęstszych przyczyn wypadków należy zaliczyćc ${ }^{12}$ :

- $\quad$ nadmierną prędkość - jest ona przyczyną około 30\% wypadków z ofiarami śmiertelnymi;

- $\quad$ wiek kierowców - młodzi kierowcy wykazują się brakiem doświadczenia i brakiem umiejętności prowadzenia pojazdu;

- coraz większa liczba nietrzeźwych kierowców,

- $\quad$ ignorowanie pozostałych uczestników ruchu, między innymi pieszych, rowerzystów i motorowerzystów.

Jak już wspomniano, nieprawidłowe zachowania uczestników ruchu wpływają na większą liczbę wypadków. Na rysunku 1 przedstawiono najczęstsze zachowania kierowców, które doprowadzają do śmiertelnych wypadków na polskich drogach. Analizując rysunek 1, można zauważyć, że największa liczba wypadków jest spowodowana nadmierną prędkością. W 2013 r. ich liczba wynosiła 8396, na skutek czego życie straciło 992 osób. Nieudzielenie pierwszeństwa przejazdu to kolejny czynnik wpływający na wzrost zagrożenia. Wynika on ze złej oceny odległości zbliżającego się pojazdu oraz braku wy-

\footnotetext{
${ }^{11}$ Ministerstwo Infrastruktury i Rozwoju, Program rozwoju gminnej i powiatowej infrastruktury drogowej na lata 2016-2020, Warszawa 2015.

${ }^{12}$ M. Goniewicz, K. Goniewicz, Wypadki drogowe w Polsce - czynniki sprawcze i zapobieganie, „Bezpieczeństwo pracy. Nauka i Praktyka" 2010/9.
} 
obraźni kierowców. Liczba osób zabitych w tym wypadku jest dużo niższa i wynosi 353 osoby. Jak wynika z badań, na stan bezpieczeństwa na polskich drogach wpływają również: nieprawidłowe przejeżdżanie przez przejścia dla pieszych, wyprzedzanie, niezachowanie bezpiecznej odległości między pojazdami oraz nieudzielenie pierwszeństwa pieszemu.

Rys. 1. Zachowania kierowców powodujące wypadki

WYPADKI

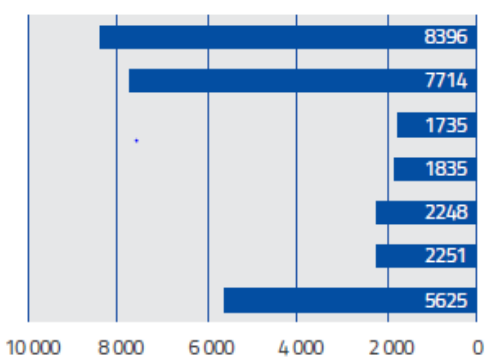

ZABICI

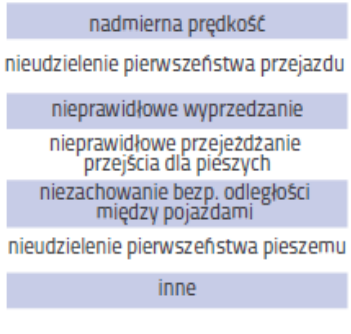

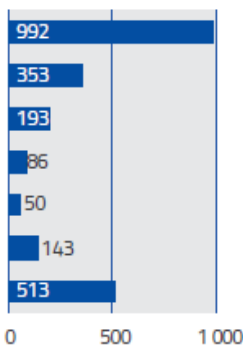

Źródło: Krajowa Rada Bezpieczeństwa Ruchu Drogowego.

Warto również zwrócić uwagę na to, że bezpieczeństwo ruchu drogowego nie zawsze zależy od zachowania kierowcy. Ważnym elementem są również czynniki bezosobowe, do których zaliczyć można chociażby: stan dróg, stan techniczny pojazdów oraz warunki zewnętrzne.

W dalszej części analizy skupiono się na licznie wypadków w poszczególnych województwach, aby ustalić, w jakich częściach Polski bezpieczeństwo ruchu drogowego jest najmniejsze. Na rysunku 2 przedstawiono szczegółowe wyniki statystyk z podziałem na: liczbę wypadków, rannych oraz ofiar śmiertelnych w poszczególnych województwach. 
Rys. 2. Liczba wypadków, rannych i ofiar śmiertelnych w 2013 r.

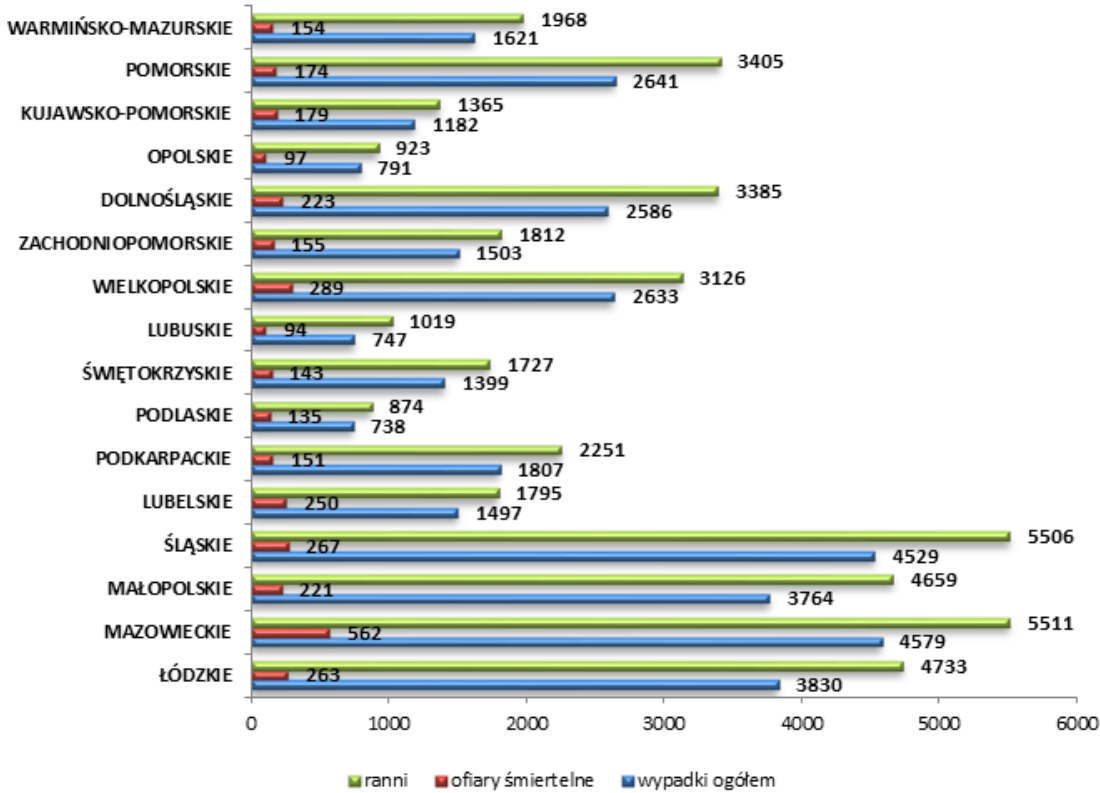

Źródło: opracowanie własne na podstawie danych z Głównego Urzędu Statystycznego.

W Polsce w 2013 r. odnotowano 35874 wypadki. Na podstawie analizy rysunku 2 można stwierdzić, że największa liczba wypadków przypada na województwo mazowieckie. Odnotowano 4579 wypadków, gdzie w ich wyniku zginęły 562 osoby i 5511 zostało rannych. Na kolejnej pozycji uplasowało się województwo śląskie, doszło tam do 4529 wypadków, rannych zostało 5506, a zginęło 267 osób. Najmniejszą liczbę wypadków odnotowano w województwie lubuskim - 747 .

\section{METODA WARDA}

Literatura przedstawia wiele metod taksonomicznych, które za pomocą odpowiednich miar i wskaźników umożliwiają porównanie obiektów opisanych przez wiele cech. Jedną $\mathrm{z}$ nich jest metoda Warda ${ }^{13}$. Wykorzystuje ona analizę wariancji do określenia odległości między skupieniami. Zmierza do minimalizacji sumy kwadratów odchyleń dowolnych dwóch skupień, które mogą zostać uformowane na każdym etapie. Metoda ta tworzy skupienia o małej wielkości, mimo to traktowana jest jako bardzo efektywna ${ }^{14}$.

Postępowanie w tej metodzie rozpoczyna się od wyznaczenia macierzy odległości dla każdej pary obiektów. W kolejnym etapie następuje wyszukiwanie par obiektów, w których wzajemna odległość jest jak najmniejsza. Następnie zakłada się, że obiekty, które zostaną połączone, będą obiektami o numerach „,p” i „,q”. Kolejna faza to łączenie obiek-

\footnotetext{
${ }^{13}$ T. Marek, Analiza skupień w badaniach empirycznych. Metody SAHN, PWN, Warszawa 1989, s. 23.

${ }^{14}$ T. Grabiński, A. Sokołowski, Z badań nad efektywnościa wybranych procedur taksonomicznych, „Zeszyty Naukowe Akademii Ekonomicznej w Krakowie" 1984/181, s. 63-79.
} 
tów w jedno nowe skupienie. Obiekt o numerze „q” zostaje usunięty, co skutkuje tym, że numery skupień o numeracji od niego większej zmniejszają się o jeden. Ostatnim etapem w metodzie Warda jest wyznaczenie odległości nowego skupienia od każdego, które powstało. Odległość nowego skupienia można wyznaczyć ze wzoru:

$$
D_{p r}=a_{1} \cdot d_{p r}+a_{2} \cdot d_{q r}+b \cdot d_{p q}
$$

gdzie:

$\mathrm{D}_{\mathrm{pr}}$ - odległość nowego skupienia od skupienia o numerze ,,r”;

$\mathrm{d}_{\mathrm{pr}}$ - odległość pierwotnego skupienia ,„p" od skupienia „,r”;

$\mathrm{d}_{\mathrm{qr}}$ - odległość pierwotnego skupienia „,q" od skupienia „r,";

$\mathrm{d}_{\mathrm{pq}}-$ wzajemna odległość pierwotnych skupień ,p” i „,q";

$\mathrm{a}_{1}, \mathrm{a}_{2}, \mathrm{~b}$ - parametry.

Rezultatem dokonanej analizy jest dendrogram, który stanowi graficzną interpretację otrzymanych wyników. W zależności od wprowadzonych założeń w badaniu (w tym przede wszystkim akceptowanej odległości taksonomicznej między obiektami ze względu na przyjęty zestaw cech) można wyodrębnić mniejsze lub większe skupienia, a co za tym idzie - większą lub mniejszą ich liczbę ${ }^{15}$.

\section{DOBÓR ZMIENNYCH DIAGNOSTYCZNYCH OKREŚLAJĄCYCH BEZ- PIECZEŃSTWO NA POLSKICH DROGACH}

Zakres badań obejmuje podział Polski ze względu na województwa, który został ustalony w 1999 r. Zmienne zaczerpnięto ze strony Głównego Urzędu Statystycznego i obejmują 2013 r. W celu określenia stanu bezpieczeństwa na polskich drogach wybrano do analizy następujące zmienne:

$\mathrm{X}_{1}$ - wypadki drogowe na 100 tys. ludności;

$\mathrm{X}_{2}$ - ranni na 100 tys. pojazdów;

$\mathrm{X}_{3}$ - ofiary śmiertelne na 100 tys. pojazdów;

$\mathrm{X}_{4}-$ drogi o nawierzchni twardej $\mathrm{km}^{2}$;

$\mathrm{X}_{5}$ - drogi o nawierzchni gruntowej $\mathrm{km}^{2}$;

$\mathrm{X}_{6}$ - motocykle na 1 mieszkańca;

$\mathrm{X}_{7}$ - samochody osobowe na 1 mieszkańca;

$\mathrm{X}_{8}-$ samochody ciężarowe na 1 mieszkańca.

Dla wyodrębnionej listy zmiennych obliczono podstawowe miary statystyczne, które zawarto w tabeli 1 .

\footnotetext{
${ }^{15}$ M. Stec, A. Janas, A. Kuliński, Grupowanie państw Unii Europejskiej ze względu na zasoby kapitału ludzkiego i intelektualnego, „Nierówności Społeczne a Wzrost Gospodarczy” 2005/6.
} 
Stan bezpieczeństwa na polskich drogach...

Tabela 1. Podstawowe miary statystyczne badanych zmiennych

\begin{tabular}{|c|l|c|c|c|c|c|}
\hline Lp. & \multicolumn{1}{|c|}{ Cecha } & Średnia & Min. & Maks. & $\begin{array}{c}\text { Odchylenie } \\
\text { standardowe }\end{array}$ & $\begin{array}{c}\text { Wspólczynnik } \\
\text { zmnienności }\end{array}$ \\
\hline 1 & Wypadki drogowe na 100 tys. ludności & 91,44 & 56,50 & 152,40 & 24,41 & 26,70 \\
\hline 2 & Ranni na 100 tys. pojazdów & 171,38 & 98,54 & 272,30 & 49,98 & 29,17 \\
\hline 3 & Ofiary śmiertelne na 100 tys. pojazdów & 13,72 & 9,55 & 17,72 & 2,61 & 19,04 \\
\hline 4 & Drogi o nawierzchni twardej km ${ }^{2}$ & 2,78 & 2,02 & 4,01 & 0,54 & 19,42 \\
\hline 5 & Drogi o nawierzchni gruntowej km ${ }^{2}$ & 39,54 & 15,85 & 116,52 & 24,60 & 62,22 \\
\hline 6 & Motocykle na 1 mieszkańca & 33,30 & 23,19 & 44,29 & 5,96 & 17,90 \\
\hline 7 & Samochody osobowe na 1 mieszkańca & 2,03 & 1,78 & 2,30 & 0,16 & 7,71 \\
\hline 8 & Samochody ciężarowe na 1 mieszkańca & 13,55 & 10,26 & 15,48 & 1,66 & 12,24 \\
\hline
\end{tabular}

Źródło: opracowanie własne na podstawie danych z Głównego Urzędu Statystycznego.

Analizując tabelę 1 , należy zwrócić uwagę, że występuje duża różnica rozpiętości współczynnika zmienności, który mieści się w przedziale 7,71-62,22\%. Najniższą wartość odnotowano przy zmiennej $X_{7}$ (samochody osobowe na 1 mieszkańca) - 7,71\%. Niska wartość tego współczynnika oznacza, że dane są jednorodne. $\mathrm{Z}$ kolei najwyższą wartością charakteryzują się drogi o nawierzchni gruntowej $\mathrm{w} \mathrm{km}^{2}(62,22 \%)$. Dla zmiennych $\mathrm{X}_{3}, \mathrm{X}_{4}, \mathrm{X}_{6}$ oraz $\mathrm{X}_{8}$ współczynnik zmienności nie przekracza $20 \%$. Dla pozostałych zaś, czyli wypadki drogowe na 100 tys. ludności i ranni na 100 tys. pojazdów, wynosi odpowiednio $26,7 \%, 29,17 \%$, co świadczy o istotnym zróżnicowaniu badanych województw.

Kolejnym etapem badań jest ustalenie relacji pomiędzy wybranymi cechami diagnostycznymi. W tabeli 2 zaprezentowano różny stopień skorelowania zmiennych.

Tabela 2. Macierz korelacji dla badanych zmiennych

\begin{tabular}{|c|c|c|c|c|c|c|c|c|}
\hline & $\mathbf{X}_{\mathbf{1}}$ & $\mathbf{X}_{\mathbf{2}}$ & $\mathbf{X}_{\mathbf{3}}$ & $\mathbf{X}_{\mathbf{4}}$ & $\mathbf{X}_{\mathbf{5}}$ & $\mathbf{X}_{\mathbf{6}}$ & $\mathbf{X}_{\mathbf{7}}$ & $\mathbf{X}_{\mathbf{8}}$ \\
\hline $\mathbf{X}_{\mathbf{1}}$ & $\mathbf{1 , 0 0}$ & 0,96 & $-0,03$ & $-0,19$ & 0,24 & 0,21 & 0,03 & $-0,29$ \\
\hline $\mathbf{X}_{\mathbf{2}}$ & 0,96 & $\mathbf{1 , 0 0}$ & $-0,08$ & $-0,08$ & 0,28 & 0,23 & 0,17 & $-0,11$ \\
\hline $\mathbf{X}_{\mathbf{3}}$ & $-0,03$ & $-0,08$ & $\mathbf{1 , 0 0}$ & 0,25 & $-0,61$ & $-0,32$ & 0,41 & 0,03 \\
\hline $\mathbf{X}_{\mathbf{4}}$ & $-0,19$ & $-0,08$ & 0,25 & $\mathbf{1 , 0 0}$ & $-0,42$ & $-0,35$ & 0,10 & 0,22 \\
\hline $\mathbf{X}_{\mathbf{5}}$ & 0,24 & 0,28 & $-0,61$ & $-0,42$ & $\mathbf{1 , 0 0}$ & 0,21 & 0,02 & 0,07 \\
\hline $\mathbf{X}_{\mathbf{6}}$ & 0,21 & 0,23 & $-0,32$ & $-0,35$ & 0,21 & $\mathbf{1 , 0 0}$ & $-0,33$ & $-0,04$ \\
\hline $\mathbf{X}_{\mathbf{7}}$ & 0,03 & 0,17 & 0,41 & 0,10 & 0,02 & $-0,33$ & $\mathbf{1 , 0 0}$ & 0,59 \\
\hline $\mathbf{X}_{\mathbf{8}}$ & $-0,29$ & $-0,11$ & 0,03 & 0,22 & 0,07 & $-0,04$ & 0,59 & $\mathbf{1 , 0 0}$ \\
\hline
\end{tabular}

Źródło: opracowanie własne na podstawie badań.

Wysokim współczynnikiem korelacji charakteryzuje się zmienna wypadki drogowe na 100 tys. ludności $\left(\mathrm{X}_{1}\right)$ ze zmienną ranni na 100 tys. pojazdów $\left(\mathrm{X}_{2}\right)$, wynosi on $\mathrm{r}_{12}=0,96$. $\mathrm{W}$ związku z tak silną zależnością należy usunąc jedną zmienną ze zbioru. W celu uzyskania poprawnych wyników $\mathrm{z}$ listy zmiennych zostanie usunięta zmienna $\mathrm{X}_{1}$ (wypadki drogowe na 100 tys. ludności). Wysoka wartość współczynnika dla tej zmiennej komunikuje o powtarzaniu się informacji. Spośród pozostałych zmiennych, które będą wykorzystywane $w$ dalszych badaniach, najwyższą dodatnią wartość współczynnika zauważa się między liczbą samochodów osobowych $\left(\mathrm{X}_{7}\right)$ a ciężarowych $\left(\mathrm{X}_{8}\right)$ w przeliczeniu na 1 mieszkańca $\left(\mathrm{r}_{78}=0,59\right)$. Zależność dodatnia umiarkowana występuje między liczbą 
ofiar śmiertelnych na 100 tys.pojazdów a liczbą samochodów osobowych na 1 mieszkańca $r_{37}=0,41$. Pozostałe wartości dodatnie charakteryzują się zależnością wyraźnie liniową, ale niską.

Z kolei najwyższy ujemny współczynnik korelacji występuje między liczbą ofiar na 100 tys. pojazdów a liczbą dróg i nawierzchni gruntowej $\mathrm{w} \mathrm{km}^{2}\left(\mathrm{r}_{35}=-0,61\right)$. Wartość tego współczynnika dla zmiennej $\mathrm{X}_{4}$ i $\mathrm{X}_{5}$ wynosi $\mathrm{r}_{45}=-0,42$ i świadczy o umiarkowanej zależności.

Brak związku liniowego występuje między zmienną $\mathrm{X}_{5}$ i $\mathrm{X}_{7}$ oraz $\mathrm{X}_{3}$ i $\mathrm{X}_{8}$, współczynniki korelacji wynoszą odpowiednio: $\mathrm{r}_{57}=0,02, \mathrm{r}_{38}=0,03$.

\section{GRUPOWANIE WOJEWÓDZTW POD WZGLEDEM STANU BEZPIE- CZEŃSTWA NA POLSKICH DROGACH ZA POMOCĄ METODY WARDA}

Wyniki grupowania stanu bezpieczeństwa na polskich drogach przedstawiono na rysunku 3.

Rys. 3. Typologia badanych województw metodą Warda.

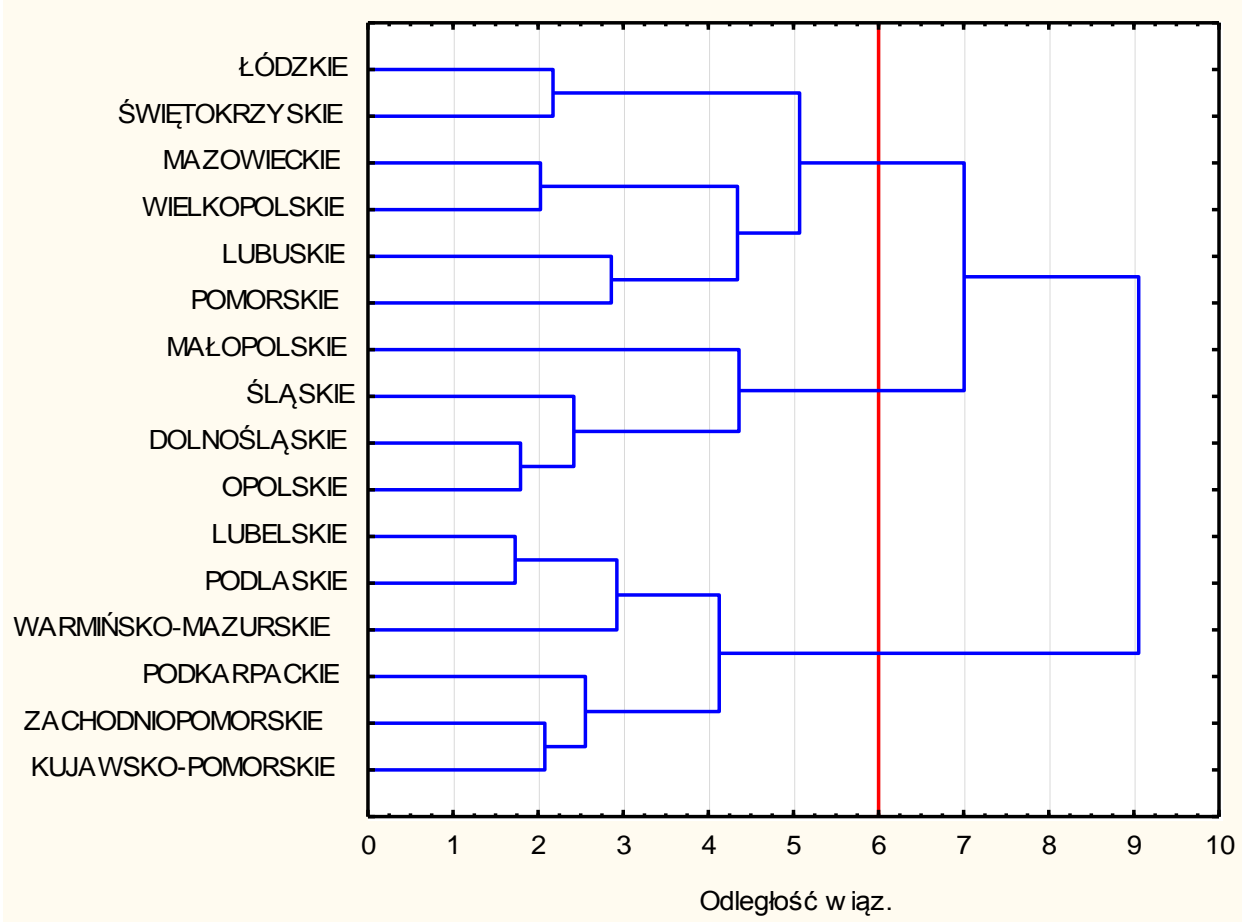

Źródło: opracowanie własne na podstawie badań.

Na rysunku 3 zaprezentowano diagram, na którego postawie ustala się liczbę skupień, przyjmując odpowiednią odległość do wyznaczenia grup. Do badań za odległość wiążącą przyjęto jednostkę 6 , dzięki czemu wyróżniono następujące grupy.

W grupie pierwszej znalazły się województwa: łódzkie, świętokrzyskie, mazowieckie, wielkopolskie, lubuskie i pomorskie. Najwyższą liczbę rannych na 100 tys. pojazdów odnotowano w województwie łódzkim (272 osoby), a najmniejszą w wielkopolskim 
(120 osób). Spośród trzech grup występuje tu najwyższa liczba osób rannych - aż 1110 osób. Z kolei liczba ofiar śmiertelnych na 100 tys. pojazdów jest najniższa w województwie wielkopolskim (11 osób), najwyższą liczbę zaś odnotowano w świętokrzyskim (17 osób). Dla tej grupy liczba dróg o nawierzchni twardej $\left[\mathrm{km}^{2}\right]$ mieści się w przedziale $2,0-4,0$, średnia wynosi $2,8 \mathrm{~km}^{2}$, a dróg o nawierzchni gruntowej $29,7 \mathrm{~km}^{2}$. Średnia liczba motocykli na 1 mieszkańca wynosi 32, największą ich liczbę odnotowano w województwie pomorskim - 38. Liczba samochodów osobowych na 1 mieszkańca mieści się w przedziale 1,77-2,1, a samochodów ciężarowych 10,25-13,15. Biorąc pod uwagę pozostałe grupy, jest to średni wynik.

Do grupy drugiej należy województwo: małopolskie, śląskie, dolnośląskie i opolskie. $\mathrm{W}$ tej grupie odnotowano najmniejszą liczbę rannych i ofiar śmiertelnych na 100 tys. pojazdów - 728 osób rannych oraz 46 ofiar śmiertelnych. Największa liczba dróg o nawierzchni twardej znajduje się w województwie opolskim $-2,53 \mathrm{~km}^{2}$. Z kolei drogi o nawierzchni gruntowej zajmują pierwszą pozycję spośród pozostałych grup, ich liczba wynosi $257,39 \mathrm{~km}^{2}$. Średnia liczba pojazdów na 1 mieszkańca wynosi: dla motocykli 40 , samochodów osobowych 2 i samochodów ciężarowych 14.

W grupie trzeciej znalazły się województwa: lubelskie, podlaskie, warmińskomazurskie, podkarpackie, zachodniopomorskie i kujawsko-pomorskie. Grupę tę wyróżnia największa liczba ofiar śmiertelnych na 100 tys. pojazdów (91 osób), najmniejszą ich liczbę odnotowano w województwie podkarpackim (11 osób). Natomiast liczba rannych na 100 tys. pojazdów również jest wysoka i wynosi 903 osób. Największą liczbą rannych charakteryzuje się województwo warmińsko-mazurskie (226 osób), a najmniejszą kujawsko-pomorskie (98 osób). Liczba dróg o nawierzchni twardej średnio dla poszczególnych województw wynosi $2,98 \mathrm{~km}^{2}$, a o nawierzchni gruntowej $-32,8 \mathrm{~km}^{2}$. Największą liczbę dróg o nawierzchni gruntowej odnotowano w województwie podkarpackim $\left(60 \mathrm{~km}^{2}\right)$. Warto zauważyć, że w tej grupie znajduje się największa liczba samochodów osobowych (13) i ciężarowych (89) na 1 mieszkańca. Średnia liczba samochodów osobowych dla tych województw wynosi 2.

Na rysunku 4 przedstawiono grupowanie województw w formie graficznej na mapie Polski.

Rys. 4. Mapa grupowania województw

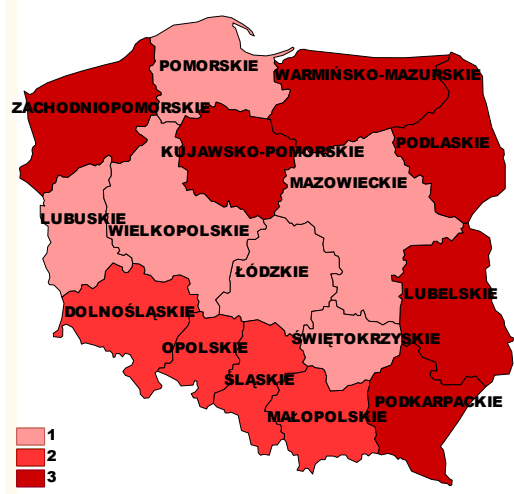

Źródło: opracowanie własne na podstawie badań. 
Analizując rysunek 4, można wnioskować, że w grupie pierwszej jest najwyższy poziom bezpieczeństwa. Do tej grupy należą województwa: łódzkie, świętokrzyskie, mazowieckie, wielkopolskie, lubuskie i pomorskie. Województwa charakteryzuje położenie w centralnej Polsce oraz duża liczba dróg o nawierzchni twardej i gruntowej, co sprzyja mniejszej liczbie wypadków. Dodatkowo liczba motocykli, samochodów osobowych i ciężarowych na 1 mieszkańca znajduje się ponad średnią.

Grupy druga i trzecia charakteryzują się podobnym poziomem bezpieczeństwa. Województwa z drugiej grupy znajdują się w południowej części Polski, a grupa trzecia we wschodniej. Należy zwrócić uwagę, że przy porównaniu tych dwóch grup największa różnica widoczna jest w liczbie dróg o nawierzchni gruntowej. W drugiej grupie liczba dróg o nawierzchni gruntowej znajduje się dużo poniżej średniej $(0,6)$, a w trzeciej powyżej średniej $(1,2)$. Dodatkowo dla drugiej grupy odnotowano mniejszą liczbę rannych osób na 100 tys. pojazdów, ale większą liczbę ofiar śmiertelnych.

\section{PODSUMOWANIE}

Na podstawie badań można stwierdzić, że zastosowana metoda Worda pozwoliła na wyodrębnienia obszarów, w których poziom bezpieczeństwa na polskich drogach jest najniższy. Po przeprowadzeniu analizy wyodrębniono trzy skupienia, na których podstawie sformułowano następujące wnioski:

- Najwyższy poziom bezpieczeństwa odnotowano w pierwszej grupie, która obejmuje teren centralnej Polski. Województwa znajdujące się w tym obszarze charakteryzuje duża liczba dróg o nawierzchni twardej i gruntowej. Świadczy to o wysokim poziomie infrastruktury drogowej, co sprzyja mniejszej liczbie wypadków drogowych.

- Skupienie drugie i trzecie charakteryzuje podobny poziom bezpieczeństwa. Druga grupa obejmuje województwa południowej Polski, gdzie liczba dróg o nawierzchni gruntowej znajduje się dużo poniżej średniej. Z kolei trzecia grupa obejmuje głównie teren Polski Wschodniej. W tym skupieniu liczba dróg o nawierzchni gruntowej znajduje się powyżej średniej.

Reasumując, należy stwierdzić, że Polska jest jednym z krajów w Unii Europejskiej, w którym odnotowana jest najwyższa liczba wypadków drogowych oraz związanych z nimi ofiar śmiertelnych. Jednak sytuacja na polskich drogach z roku na rok się poprawia. W przeliczeniu na milion mieszkańców dla roku 2001 liczba ofiar śmiertelnych wynosiła 145, a w 2013 r. liczba ta zmniejszyła się i wyniosła $87^{16}$. Wpływ na te zmiany mają niewątpliwie poprawa infrastruktury drogowej oraz zaostrzone przepisy ruchu drogowego. Warto zwrócić uwagę na to, że głównym czynnikiem powodującym zagrożenie jest człowiek. Należy więc konsekwentnie realizować zadania, których celem będzie wzrost świadomości społeczeństwa co do zagrożeń i konsekwencji, z jakimi wiążą się wypadki drogowe.

Wraz z przystąpieniem Polski do Unii Europejskiej można zauważyć wiele zmian na naszych drogach. Są to rezultaty intensywnych działań, które mają na celu modernizację i rozbudowę obecnej infrastruktury. Przez lata ulepszono nadzór w ruchu drogowym, jak

${ }^{16}$ http://odszkodowanialider.pl/s, warto-zdjac-noge-z-gazu-statystyki-wypadkow-drogowych,100.html. 
również udoskonalono system ratownictwa. $\mathrm{Z}$ roku na rok bezpieczeństwo na naszych drogach regularnie się poprawia, coraz mniej odnotowuje się wypadków drogowych, a liczba ofiar śmiertelnych spada. Jednak Krajowa Rada Bezpieczeństwa Ruchu Drogowego stale przypomina o przestrzeganiu przepisów ruchu drogowego oraz kulturze jazdy. Największe zagrożenie na drodze stanowią użytkownicy, którzy prowadzą pojazd pod wpływem alkoholu lub przekraczają dozwoloną prędkość.

\section{LITERATURA}

[1] Baran J. i in., Logistyka. Wybrane zagadnienia, SGGW, Warszawa 2008.

[2] Chudy-Laskowska K., Pisula T., Prognoza liczby wypadków drogowych w Polsce, „Logistyka" 2014/6.

[3] Globalny Plan Dekady Działań na rzecz Bezpieczeństwa Ruchu Drogowego 2011-2020, ITS BRD 2011/1, http://www.who.int/roadsafety/decade_of_action/plan/plan_english .pdf.

[4] Goniewicz M., Goniewicz K., Wypadki drogowe w Polsce - czynniki sprawcze i zapobieganie, „Bezpieczeństwo pracy. Nauka i Praktyka” 2010/9.

[5] Grabiński T., Sokołowski A., Z badań nad efektywnościa wybranych procedur taksonomicznych, ,Zeszyty Naukowe Aakademii Ekonomicznej w Krakowie” 1984/181.

[6] http://eur-lex.europa.eu/legal-content/pl/TXT/PDF/?uri=CELEX:52011DC0144.

[7] http://odszkodowanialider.pl/s, warto-zdjac-noge-z-gazu-statystyki-wypadkowdrogowych, 100.html.

[8] http://www.who.int/en/.

[9] Kos B., Kierunek poprawy efektywności zarządzania siecia drogowa w Polsce, „Studia Ekonomiczne. Zeszyty Naukowe Uniwersytetu Ekonomicznego w Katowicach" 2013/136.

[10] Krajowa Rada Bezpieczeństwa Ruchu Drogowego, Stan bezpieczeństwa ruchu drogowego oraz działania realizowane w tym zakresie, Warszawa 2013.

[11] Krajowa Rada Bezpieczeństwa Ruchu Drogowego, Wycena kosztów wypadków i kolizji drogowych na sieci dróg w Polsce na koniec roku 2013, Warszawa 2014.

[12] Marek T., Analiza skupień w badaniach empirycznych. Metody SAHN, PWN, Warszawa 1989.

[13] Ministerstwo Infrastruktury i Rozwoju, Program rozwoju gminnej i powiatowej infrastruktury drogowej na lata 2016-2020, Warszawa 2015.

[14] Stajniak M. i in., Transport i spedycja, Instytut Logistyki i Magazynowania, Poznań 2008.

[15] Stec M., Janas A., Kuliński A., Grupowanie państw Unii Europejskiej ze względu na zasoby kapitału ludzkiego i intelektualnego, „Nierówności Społeczne a Wzrost Gospodarczy” 2005/6.

\section{SAFETY STATUS ON POLISH ROADS IN 2013}

Road transport is one of the crucial areas of functioning of contemporary Poland. It allows the mobility of the population and satisfies the demand for a quick delivery of goods. The growing number of vehicles and the increase in traffic causes that it becomes necessary for the development of road networks and their qualitative changes. Road transport infrastructure should, therefore, comply with all the necessary conditions that will be able to meet the ever increasing requirements of society. Expansion of road system, or upgrading existing ones is a necessary condition for safe and quick movement. The publication also highlights the impacts that incur accidents and collisions caused on Polish roads. According to the National Road Safety Council in 2013 their costs amounted to 41.9 billion, which represented $2.99 \%$ of GDP. These resources could be successfully used for other social purposes, such as education or healthcare. Therefore, the main objective of this article is to present safety status on Polish roads with a voivodship division. The paper presents the results of surveys on road accidents and their victims in 2013. For the tests theStatistica PL was 
applied. The data were taken from the Central Statistical Office. The evaluation of the diagnosis was made using the Ward's method. It was used to separated three clusters, which allowed the province to identify terms of features adopted.

Keywords: road transport, safety, accident victims, the method Ward

\section{DOI: 10.7862/rz.2016.mmr.13}

Tekst złożono w redakcji: sierpień 2016

Przyjęto do druku: wrzesień 2016 